\title{
Effects of Feeding Different Sorghum Varieties on the Haematological Parameters and Carcass Measurements of Growing Rabbits
}

\author{
Mohammed, G., Igwebuike, J.U., Adamu, S.B., Asheikh, L.G., Maru, A.S., Yalma, J \\ and Kolo, U.M* \\ Department of Animal Science, University of Maiduguri, P.M.B 1069, Maiduguri, Nigeria \\ (*uskolo220@gmail.com).
}

\begin{abstract}
An eight-week feeding trial was conducted to investigate the effect of different sorghum varieties on the blood parameters and carcass measurements of cross-bred (Dutch $\mathrm{x}$ New Zealand) growing rabbits aged between five and seven weeks. Twenty five rabbits were randomly allocated to five dietary treatments; T1 (100\% maize), T2 (50\% maize and 50\% "Chakalare" sorghum), T3 (100\% Chakalare" sorghum), T4 (50\% maize and 50\% "Jigare" sorghum) and T5 (100\% "Jigare" sorghum). The "Chakalare" and "Jigare" are low-tannin and high- tannin sorghum varieties respectively. The haematological parameters were Packed Cell Volume (PCV), Haemoglobin (Hb), Red Blood Cell (RBC), White Blood Cell (WBC), Mean Corpuscular Volume (MCV), Mean Corpuscular Haemoglobin (MCH), Mean Corpuscular Haemoglobin Concentration (MCHC), Monocytes (\%) basophils (\%), Neutrophils (\%), Eosinophils (\%) and Lymphocytes (\%). The carcass parameters were Slaughter weight (g), Dressed weight (g), Dressing percentage \%, (As \% of slaughter weight) of Shoulder/forelegs, Rack, Loin, Thighs/Hind legs, Skin/pelt, Tail, Head, Feet, Heart Liver, Lungs, Kidneys, Kidneys Caecum, Stomach, Large intestine, Small intestine, Caecum length $(\mathrm{cm})$, Stomach length $(\mathrm{cm})$, Small intestine length $(\mathrm{cm})$ and Body length $(\mathrm{cm})$. The response showed that most of the haematological parameters were significantly affected $(\mathrm{P}<0.05)$ by the different varieties of sorghum in the diets except packed cell volume, mean corpuscular volume, mean corpuscular haemoglobin concentration and basophils which were not significantly affected $(\mathrm{P}>0.05)$ by the different varieties of sorghum in the diets. However, most of the haematological values fell within the normal ranges PCV (37.33 to $40.67 \%), \mathrm{Hb}$ (13.37- $156.73 \%), \mathrm{RBC}(5.57-6.93 \%)$ and WBC (12.67-14.83) of growing rabbits. The carcass measurements and organs expressed as percentage of slaughter weight were not significantly $(\mathrm{P}>0.05)$ different among the treatment groups except slaughter weight, dressing percentage, rack, loin, liver, caecum weight and stomach length which were significantly $(\mathrm{P}<0.05)$ different. The study indicated that the two varieties of sorghum ("Chakalare" and "Jigare") can be included in the diets of growing rabbits as replacement for maize without adverse effect on haematology and carcass parameters of growing rabbits.
\end{abstract}

Keywords: Growing rabbits, Sorghum varieties, Haematological parameters and carcass measurements, Nigeria.

\section{INTRODUCTION}

The level of performance in the livestock industries in Nigeria in recent years has fallen below expectation due to shortage of feed, escalating prices of feed ingredients and poor quality feed (Owen et al., 2009). Recent difficulties with animal production inputs in Nigeria, especially high cost of feed ingredients in particular, have brought about the need to look for alternatives to conventional feed resources. These led to the need to explore other locally 
available and relatively cheaper feed materials such as brewers' dried grain, rice bran, maize bran and millet bran (Mohammed et al., 2008).

In most developing countries the search for non-conventional feed ingredients to replace the expensive conventional ones appears to occupy the attention of the animal nutritionists. It is to reduce the cost of production, thus making it possible for people to afford animal protein in their menu (Ojebiyi et al., 2006). The objectives of this study is to determine the effect of feeding different varieties of sorghum on the haematology and carcass measurements of growing rabbits.

\section{MATERIALS AND METHODS}

\subsection{Location of the study}

The study was conducted at the Livestock Teaching and Research Farm, Department of Animal Science, University of Maiduguri, Maiduguri, Borno State, Nigeria. Maiduguri is located on latitude $11^{\circ} 15^{\prime}$ North and longitude $30^{\circ} 05^{\prime}$ East and on an altitude of $345 \mathrm{~m}$ above sea level (Ugherughe and Ekedolum, 1986). The relative humidity ranges from 30 to $50 \%$. The area experiences for 3 to 4 months from June to September and gets between 500 to $600 \mathrm{~mm}$ and followed by long period of dry season of 8 months (Encarta, 2007).

\subsection{Experimental animals and management.}

A total of twenty-five (25) Dutch x New Zealand white rabbits, between five and seven weeks of age were used for the feeding trial which lasted for 8 weeks. Before the commencement of the experiment, a one-week adjustment period was observed. The rabbits were individually weighed and divided into five groups with average weight of $569.4 \mathrm{~g}$. The groups were randomly assigned to five dietary treatments. Each rabbit was individually housed in a wire cage measuring $38 \times 33 \times 45 \mathrm{~cm}$. The cages, in rows, were raised $45 \mathrm{~cm}$ above the ground to facilitate cleaning. Each cage cell was equipped with plastic drinker and metal feeding trough. The experimental diets (in mash form) and clean drinking water were provided ad libitum throughout the experimental period.

\subsection{Experimental diets}

The experimental diets and their proximate composition are shown in table 1 . The five (5) diets were designated as Treatment 1 (control; 100\% maize and 0\% sorghum), Treatment 2 (50\% "Chakalare" sorghum and 50\% maize), Treatment 3 (100\% "Chakalare" sorghum), Treatment 4 (50\% "Jigare" sorghum and 50\% maize) and Treatment 5 (100\% "Jigare 
sorghum). The "Chakalare" and "Jigare" are low-tannin and high-tannin sorghum varieties respectively.

Table 1. Ingredients and proximate composition of the experimental diets.

\begin{tabular}{|c|c|c|c|c|c|}
\hline Ingredients & $\begin{array}{l}T 1 \\
(100 \% \\
\text { Maize })\end{array}$ & $\begin{array}{l}T 2 \\
(50 \% \\
\text { "Chakalare" } \\
\text { sorghum) }\end{array}$ & $\begin{array}{l}\text { T3 } \\
\text { (100\% } \\
\text { “Chakalare" } \\
\text { sorghum) }\end{array}$ & $\begin{array}{c}\text { T4 } \\
\text { ( 50\% } \\
\text { “Jigare" } \\
\text { sorghum) }\end{array}$ & $\begin{array}{c}\text { T5 } \\
\text { ( } 100 \% \\
\text { “Jigare”, } \\
\text { sorghum) }\end{array}$ \\
\hline Maize & 34.00 & 17.00 & 0.00 & 17.00 & 0.00 \\
\hline Sorghum (“Chakalere”) & 0.00 & 17.00 & 34.00 & 0.00 & 0.00 \\
\hline Sorghum ("Jigare") & 0.00 & 00.00 & 0.00 & 17.00 & 34.00 \\
\hline Wheat offal & 17.00 & 17.00 & 17.00 & 17.00 & 17.00 \\
\hline Groundnut cake & 16.45 & 16.45 & 16.45 & 16.45 & 16.45 \\
\hline Fish meal & 3.00 & 3.00 & 3.00 & 3.00 & 3.00 \\
\hline Groundnut haulms & 27.00 & 27.00 & 27.00 & 27.00 & 27.00 \\
\hline Limestone & 2.00 & 2.00 & 2.00 & 2.00 & 2.00 \\
\hline Common Salt $(\mathrm{NaCl})$ & 0.25 & 0.25 & 0.25 & 0.25 & 0.25 \\
\hline Premix* & 0.30 & 0.30 & 0.30 & 0.30 & 0.30 \\
\hline Total & 100.00 & 100.00 & 100.00 & 100.00 & 100.00 \\
\hline \multicolumn{6}{|l|}{$\begin{array}{l}\text { Proximate } \\
\text { composition }\end{array}$} \\
\hline Crude protein $(\%)$ & 19.77 & 19.94 & 20.11 & 19.94 & 20.11 \\
\hline Crude fibre $(\%)$ & 9.27 & $9 . .89$ & 10.57 & 10.02 & 10.98 \\
\hline Ether extract (\%) & 3.64 & 3.40 & 3.13 & 3.97 & 3.31 \\
\hline Ash (\%) & 5.00 & 3.00 & 2.00 & 3.00 & 4.00 \\
\hline $\begin{array}{l}\text { Metabolizable Energy } \\
\text { (Kcal } / \mathrm{kg})\end{array}$ & 2563.97 & 2618.19 & 2643.72 & 2635.93 & 2572.73 \\
\hline
\end{tabular}

Note: * Premix (grow fast) Manufactured by Animal Care Service Consult (Nig) Ltd. Lagos, supplying the following per $\mathrm{kg}$ of premix: Vitamin A, 5000,00 IU; Vitamin $\mathrm{D}_{3} 800,000$ IU; Vitamin E, 12,000 mg; Vitamin K, 1,5000 mg; Vitamin $\mathrm{B}_{1}, 1,000 \mathrm{mg}$; Vitamin b2, 2,000 mg; Vitamin $\mathrm{B}_{6}, 1,500 \mathrm{mg}$; niacin, 12,000 mg; pantothenic acid, $20.00 \mathrm{mg}$; biotin, $10.00 \mathrm{mg}$; Vitamin $\mathrm{B}_{12}, 300.00 \mathrm{mg}$; folic acid, 150,000 mg; choline, 60,000 mg; manganese, 10,000 mg; iron, $15,000 \mathrm{mg}$; zinc, $800.00 \mathrm{mg}$; copper, $400.00 \mathrm{mg}$; iodine, $80.00 \mathrm{mg}$; cobalt, $40 \mathrm{mg}$; selenium $8.00 \mathrm{mg}$;

\subsection{Haematological parameters}

At week 8 of the experiment, blood samples were collected randomly from three (3) rabbits per treatment for the determination of the haematological indices. Samples were collected from the ear vein of the rabbits by venipunture using disposable needle (21-gauge needle) and syringes. The rabbits were fasted overnight (12 hrs) and normally bled in the morning (7.00-8.00 am) to avoid excessive bleeding. The collection site was cleaned with alcohol and xylene to dilate the veins. Sterile cotton was used to cover the punctured vein after collection. The blood samples were collected in sample bottles containing dipotassium salt of ethylene 
diamine-tetra acetic acid (EDTA- $\mathrm{K}^{2+}$ ) which served as an anticoagulant. The haematological analysis of blood samples were carried out at the Department of Veterinary Public Health, Faculty of Veterinary Medicine, University of Maiduguri, Nigeria, using the routinely available clinical methods (Schalm et al., 1975; Encarta, 2007). The haematological indices determined were packed cell volume (PCV), haemoglobin concentration $(\mathrm{Hb})$, red blood cell (RBC) counts and white blood cell (WBC) counts and differential counts. Mean corpuscular haemoglobin $(\mathrm{MCH})$, mean corpuscular volume $(\mathrm{MCV})$ and mean corpuscular haemoglobin concentration (MCHC) were obtained by calculation according to standard formulae (Jain, 1986).

\subsection{Carcass measurements}

At the end of the experiment, three rabbits from each treatment were selected for slaughter based on average weight of the group. They were deprived of feed for 12 hours as recommended by Jain (1986) but drinking water was provided. Withholding feed for 12 hours before slaughter reduced the volume of gut contents and hence bacteria, and therefore reduced the risk of carcass contamination during dressing without adversely affecting meat yield and quality (Jain, 1986; FAO. 1991). The rabbits were weighed in the morning and slaughtered by cutting transversely across the trachea, oesophagus, large carotid arteries and jugular veins to ensure maximum bleeding (Mann, 1960). They were later opened and dressed as described by (Blasco et al., 1993). The dressed carcass is the portion of the rabbit remaining after the removal of the head, feet, skin (pelt), tail and visceral organs including kidneys. The dressed carcasses were split into retail cuts such as shoulder/forelegs, thigh/hind leg, rack and loin as described by (Blasco et al., 1993). The dressed carcass and the retail cuts were weighed and expressed as percentage of slaughter weight.

Dressing percentage $=\frac{\text { Dressed carcass } W t .(g)}{\text { Slaughter } \text { weight }(g)} \times 100$

\subsection{Statistical analysis}

All the data collected were subjected to analysis of variance (ANOVA) using the randomized complete block design (Steel and Torrie, 1980). Means were separated where applicable using the Duncan's multiple range test (Duncan, 1955). A computer package (Statistix 9.0) was used for the analysis. 


\section{RESULTS AND DISCUSSION}

\subsection{Haematology}

The haematological values obtained for rabbits on different treatment groups are presented in table 2. The haematological parameters were significantly $(\mathrm{P}<0.05)$ affected by the different varieties of sorghum except packed cell volume (PCV), mean corpuscular volume (MCV), mean corpuscular haemoglobin concentration (MCHC) and basophils which were not significantly $(\mathrm{P}>0.05)$ different among the treatment groups. The packed cell volume $(\mathrm{PCV})$ fell within the normal range of 31 to $50 \%$ for healthy growing rabbits as reported by (Anon, 1980).

Table 2. Haematological indices of rabbits fed different varieties of sorghum as replacement for maize.

\begin{tabular}{|c|c|c|c|c|c|c|}
\hline & $T 1$ & $T 2$ & $T 3$ & T4 & $T 5$ & \\
\hline Indices & $\begin{array}{l}\text { (100\% } \\
\text { Maize } \\
+0 \% \\
\text { sorghum) }\end{array}$ & $\begin{array}{l}50 \% \\
\text { Maize } \\
+50 \% \\
\text { “Chakalare } \\
\text { sorghum") }\end{array}$ & $\begin{array}{l}(0 \% \\
\text { maize } \\
+100 \% \\
\text { "Chakalar" } \\
\text { sorghum) }\end{array}$ & $\begin{array}{l}(50 \% \\
\text { maize } \\
+50 \% \\
\text { “Jigar" } \\
\text { sorghum) }\end{array}$ & $\begin{array}{l}(0 \% \\
\text { Maize } \\
+100 \% \\
\text { "Jigare" } \\
\text { sorghum) }\end{array}$ & SEM \\
\hline PCV (\%) & 40.67 & 37.33 & 40.67 & 39.00 & 40.00 & $2.374^{\mathrm{NS}}$ \\
\hline $\mathrm{Hb}(\mathrm{g} / 100 \mathrm{ml})$ & $13.93^{\mathrm{b}}$ & $13.73^{b}$ & $14.03^{b}$ & $13.83^{b}$ & $15.73^{\mathrm{a}}$ & $0.54^{*}$ \\
\hline $\operatorname{RBC}\left(\times 10^{6} / \mathrm{mm}^{3}\right)$ & $6 . .55^{\mathrm{a}}$ & $5.57^{\mathrm{a}}$ & $6.75^{\mathrm{a}}$ & $6.87^{\mathrm{a}}$ & $6.93^{\mathrm{b}}$ & $0.18^{*}$ \\
\hline WBC $\left(x 10^{3} / \mathrm{mm}^{3}\right)$ & $14.83^{\mathrm{a}}$ & $13.78^{\mathrm{ab}}$ & $12.67^{b}$ & $13.87^{\mathrm{ab}}$ & $13.22^{\mathrm{ab}}$ & $0.76^{*}$ \\
\hline $\mathrm{MCV}(\mathrm{fl})$ & 60.15 & 60.80 & 60.03 & 50.70 & 50.70 & $0.54^{\mathrm{NS}}$ \\
\hline $\mathrm{MCH}(\mathrm{pg})$ & $21.28^{b}$ & $24.97^{\mathrm{a}}$ & $20.78^{b}$ & $20.15^{b}$ & $22.70^{\mathrm{ab}}$ & $1.15^{*}$ \\
\hline MCHC (\%) & 34.57 & 36.88 & 34.77 & 35.53 & 39.33 & $2.24^{\mathrm{NS}}$ \\
\hline \multicolumn{7}{|l|}{ Differential counts } \\
\hline Monocytes (\%) & $10.00^{\mathrm{bc}}$ & $11.00^{\mathrm{ab}}$ & $10.00^{\mathrm{bc}}$ & $12.33^{\mathrm{a}}$ & $8.33^{\mathrm{c}}$ & $0.93^{*}$ \\
\hline Basophils (\%) & 1.00 & 0.33 & 1.00 & 0.33 & 0.67 & $0.54^{\mathrm{NS}}$ \\
\hline Neutrophils (\%) & $34.67^{\mathrm{ab}}$ & $32.67^{b}$ & $34.00^{b}$ & $35.67^{\mathrm{ab}}$ & $36.00^{\mathrm{a}}$ & $1.28^{*}$ \\
\hline Eosinophils (\%) & $7.67^{b}$ & $8.00^{\mathrm{ab}}$ & $7.33^{b}$ & $10.00^{\mathrm{a}}$ & $8.67^{\mathrm{ab}}$ & $0.87^{*}$ \\
\hline Lymphocytes (\%) & $47.67^{\mathrm{a}}$ & $48.00^{\mathrm{a}}$ & $48.67^{\mathrm{a}}$ & $41.67^{b}$ & $46.33^{\mathrm{ab}}$ & $2.46^{*}$ \\
\hline
\end{tabular}

Note: $\mathrm{PCV}=$ Packed cell volume; $\mathrm{Hb}=$ Haemoglobin concentration; $\mathrm{SEM}=$ Standard error of means, NS $=$ Not significant $(\mathrm{P}>0.05),{ }^{*}=$ Significant $(\mathrm{P}<0.05), \mathrm{a}, \mathrm{b}, \mathrm{c}=$ means in the same row bearing different superscripts differ significantly $(\mathrm{P}<0.05), \mathrm{RBC}=\mathrm{Red}$ blood cells count, $\mathrm{WBC}=$ White blood cells count, $\mathrm{MCV}=$ Mean corpuscular volume, $\mathrm{MCH}=$ Mean corpuscular haemoglobin, $\mathrm{MCHC}=$ Mean corpuscular haemoglobin concentration

Rabbits fed with the T5 (100\% "Jigare" sorghum) diet had significantly $(\mathrm{P}<0.05)$ higher haemoglobin concentration $(\mathrm{Hb})$ compared to other groups. However, the values (13.83 $15.73 \mathrm{~g} / 100 \mathrm{ml})$ for all the groups fell within the normal ranges of 8 to $17 \mathrm{~g} / 100 \mathrm{ml}$ and $(9.4-$ $17.4 \mathrm{~g} / 100 \mathrm{ml}$ as reported by (Anon, 1980; Mitruka and Rawnsley, 1997). The rabbits fed on 
T5 (100\% "Jigare" sorghum) diet however, had lower red blood cell counts (RBC) compared to the other treatments but the values for all the treatment groups fell within the normal ranges of 5 to $8.0 \times 10^{6} / \mathrm{mm}^{3}$ as reported by (Anon, 1980; Ahamefule et al., 2008). Rabbits fed on control diets ( $0 \%$ sorghum) had higher white blood cell count than those on T3 $(100 \%$ "Chakalare" sorghum) diet but did not differ from rabbits fed T2 (50\% "Chakalare" sorghum), T4 (50\% "Jigare" sorghum) and T5 (100\% "Jigare" sorghum) diets respectively. The values $\left(12.67-14.83 \times 10^{6} / \mathrm{mm}^{3}\right)$ obtained in this study were close to the value of 3.0 to $12.5 \times 10^{6} / \mathrm{mm}^{3}$ reported by (Anon, 1980). The MCV values obtained in this study were close to the reference values of 60 to $73 \mathrm{fl}$ and 67.9 to $73.9 \mathrm{fl}$ reported by (Anon, 1980; Ahamefule et al.,2008) while the MCHC values recorded also were close to the normal range of 26 to 34\% (Anon, 1980). Rabbits fed T2 (50\% "Chakalare" sorghum) diet had higher mean corpuscular haemoglobin $(\mathrm{MCH})$ than the control (0\% sorghum), T3 (100\% "Chakalare" sorghum) and T4 (50\% "Jigare" sorghum) diets but similar ( $>0.05)$ to T5 (100\% "Jigare" sorghum) diet. The values $(20.15-24.97 \mathrm{pg})$ in this study were close to the reference values of 16 to elsewhere (Anon, 1980).

The rabbits fed with T4 (50\% "Jigare" sorghum) diet has superior value of monocytes than the control (1000\% maize), T3 (100\% "Chakalare" sorghum) and T5 (100\% "Jigare" sorghum) diets but did not differ $(\mathrm{P}>0.05)$ from rabbits fed T2 $(50 \%$ "Chakalare" sorghum $)$ diet while inferior value was recorded in T5 (100\% "Jigare" sorghum) diet. The basophils fell within the normal ranges of 0.73 to $2.12 \%$ reported by Mann (1960). The rabbits fed T5 (100\% "Jigare" sorghum) diet had higher neutrophils compared to T2 (50\% "Chakalare" sorghum) and T3 (100\% "Chakalare" sorghum) diets but similar to control (100\% maize) and T4 (50\% "Jigare" sorghum) diets. The neutrophils values (32.67 to $36.00 \%)$ were within the normal range of $35.02-43.20 \%$ for young rabbits (Mitruka and Rawnsley, 1997). Eosinophils for rabbits fed T4 (50\% "Jigare" sorghum) diet was higher than the control (100\% maize) and T3 (100\% "Chakalare" sorghum) diets but similar to T2 (50\% "Chakalare" sorghum) and T5 (100\% sorghum Jigare) diets. The values $(7.37-10.00 \%)$ were close to the reference values $(10-12.5 \%)$ reported by Ahamefule et al. (2003) for healthy growing rabbits. Lymphocyte for rabbits fed control ( $0 \%$ sorghum), T2 (50\% "Chakalare" sorghum) and T3 (100\% "Chakalare" sorghum) diets had higher values than those rabbits fed T4 (50\% "Jigare" sorghum) diet but similar to T5 (100\% "Jigare" sorghum) diet. The observed values suggested that the different varieties of sorghum had no adverse effect on haematological 
parameters, thus indicating that maize could be completely replaced with low- tannin and high-tannin sorghum in the diets of growing rabbits.

\subsection{Carcass parameters}

The carcass parameters in table 3 showed that dressed weight, shoulder, thighs, head, skin, feet, tail, small intestine, large intestine, stomach, heart, kidneys, lungs, caecum length, small intestine length, large intestine length and body length were not significantly $(\mathrm{P}>0.05)$ different among the treatment groups. This is an indication that body and organ developments of the growing rabbits were not compromised by the different varieties of sorghum included in their diets.

Table 3. Carcass measurements and organs of rabbits fed different varieties of sorghum as replacement for maize.

\begin{tabular}{|c|c|c|c|c|c|c|}
\hline & $T 1$ & $T 2$ & $T 3$ & $T 4$ & $T 5$ & \\
\hline Parameters & $\begin{array}{l}\text { (100\% } \\
\text { Maize } \\
+0 \% \\
\text { sorghum) }\end{array}$ & $\begin{array}{l}\text { (50\%maize } \\
+50 \% \\
\text { “Chakalares } \\
\text { orghum) }\end{array}$ & $\begin{array}{l}\text { 0\% maize } \\
+100 \% \\
\text { "Chakalare" } \\
\text { sorghum) }\end{array}$ & $\begin{array}{l}50 \% \\
\text { maize+50 } \\
\% \text { “Jigare" } \\
\text { sorghum) }\end{array}$ & $\begin{array}{l}\text { (0\% maize } \\
+100 \% \\
\text { "Jigare" } \\
\text { sorghum) }\end{array}$ & SEM \\
\hline No. of rabbits & 3 & 3 & 3 & 3 & 3 & - \\
\hline Slaughter wt (g) & $1157.70^{\mathrm{b}}$ & $1196.70^{\mathrm{b}}$ & $1223.30^{\mathrm{ab}}$ & $1304.00^{\mathrm{a}}$ & $1352.00^{\mathrm{a}}$ & $70.14 *$ \\
\hline Dressed wt (g) & 523.00 & 596.67 & 592.67 & 581.67 & 572.00 & $67.44^{\mathrm{NS}}$ \\
\hline Dressing $(\%)$ & $45.80^{\mathrm{ab}}$ & $4986^{\mathrm{a}}$ & $48.45^{\mathrm{a}}$ & $44.61^{\mathrm{ab}}$ & $42.31^{\mathrm{b}}$ & $1.40 *$ \\
\hline \multicolumn{7}{|c|}{ As \% of slaughter weight } \\
\hline Shoulder/forelegs & 30.76 & 30.19 & 31.31 & 31.48 & 34.31 & $1.22^{\mathrm{NS}}$ \\
\hline Rack & $10.69^{\mathrm{a}}$ & $8.64^{b}$ & $7.47^{b}$ & $8.48^{b}$ & $9.96^{\mathrm{b}}$ & $0.92 *$ \\
\hline Loin & $17.94^{\mathrm{b}}$ & $20.67^{\mathrm{ab}}$ & $20.11^{\mathrm{ab}}$ & $22.62^{\mathrm{a}}$ & $19.46^{\mathrm{ab}}$ & $0.99 *$ \\
\hline Thighs/Hind legs & 40.29 & 40.60 & 41.47 & 44.04 & 43.37 & $1.94^{\mathrm{NS}}$ \\
\hline Skin/pelt & 18.57 & 18.90 & 17.74 & 21.37 & 22.15 & $1.75^{\mathrm{NS}}$ \\
\hline Tail & 1.06 & 0.67 & 0.78 & 1.23 & 1.12 & $0.75^{\mathrm{NS}}$ \\
\hline Head & 22.03 & 20.20 & 21.46 & 21.69 & 23.43 & $1.62^{\mathrm{NS}}$ \\
\hline Feet & 6.58 & 4.90 & 5.99 & 5.89 & 5.28 & $0.75^{\mathrm{NS}}$ \\
\hline Heart & 0.69 & 0.73 & 0.65 & 0.82 & 0.77 & $0.12^{\mathrm{NS}}$ \\
\hline Liver & $7.73^{\mathrm{ab}}$ & $6.08^{b}$ & $8.45^{\mathrm{a}}$ & $8.79^{a}$ & $8.81^{\mathrm{a}}$ & $0.64 *$ \\
\hline Lungs & 1.68 & 1.84 & 1.71 & 1.76 & 1.92 & $0.28^{\mathrm{NS}}$ \\
\hline Kidneys & 1.91 & 1.79 & 1.67 & 1.94 & 1.99 & $0.23^{\mathrm{NS}}$ \\
\hline Stomach & 11.52 & 7.16 & 8.55 & 10.12 & 9.76 & $1.85^{\mathrm{NS}}$ \\
\hline Caecum & $20.45^{\mathrm{a}}$ & $15.77^{\mathrm{ab}}$ & $11.14^{\mathrm{b}}$ & $17.96^{\mathrm{a}}$ & $18.59^{\mathrm{a}}$ & $1.78 *$ \\
\hline Large intestine & 7.87 & 5.88 & 5.68 & 6.11 & 7.47 & $0.75^{\mathrm{NS}}$ \\
\hline Small intestine & 7.64 & 6.72 & 7.35 & 7.72 & 7.59 & $0.69^{\mathrm{NS}}$ \\
\hline Caecum length $(\mathrm{cm})$ & 43.67 & 45.67 & 43.00 & 44.67 & 51.17 & $3.49^{\mathrm{NS}}$ \\
\hline Stomach length(cm) & $11.17^{\mathrm{a}}$ & $8.67^{b}$ & $8.17^{b}$ & $8.83^{b}$ & $7.83^{b}$ & $0.60 *$ \\
\hline $\begin{array}{l}\text { Small intestine } \\
\text { length }(\mathrm{cm})\end{array}$ & 242.00 & 232.67 & 239.00 & 224.67 & 246.67 & $19.43^{\mathrm{NS}}$ \\
\hline $\begin{array}{l}\text { Large intestine } \\
\text { length }(\mathrm{cm})\end{array}$ & 101.83 & 108.00 & 93.33 & 94.67 & 86.33 & $7.49^{\mathrm{NS}}$ \\
\hline Body length $(\mathrm{cm})$ & 29.33 & 31.00 & 28.83 & 30.50 & 28.00 & $1.31^{\mathrm{NS}}$ \\
\hline
\end{tabular}

Note: $\mathrm{SEM}=$ Standard error of means; $\mathrm{NS}=$ Not significant $(\mathrm{P}>0.05) ; *=$ Significant $(\mathrm{P}<$ $0.05) ; a, b, c=$ means in the same row bearing different superscripts differ significantly $(\mathrm{P}<0.05)$. 
The slaughter weight, dressing percentage, rack, loin, liver, caecum weight and stomach length were significantly $(\mathrm{P}<0.05)$ different among the treatment groups. Rabbits fed $\mathrm{T} 5$ (100\% "Jigare" sorghum) and T4 (50\% "Jigare" sorghum) diets had significantly $(\mathrm{P}<0.05)$ heavier slaughter weight than those fed T1 (100\% maize) and T2 (50\% "Chakalare" sorghum) diets. There were no significant difference in slaughter weight among the rabbits fed the T3 (100\% "Chakalare" sorghum) diet and the other diets. Rabbits fed T2 (50\% "Chakalare" sorghum) and T3 (100\% "Chakalare" sorghum) diets had significantly better dressing percentage than those on T5 (100\% "Jigare"sorghum) diet but was similar to other treatment groups.

Rabbits fed the control $(100 \%$ maize $)$ diet had significantly $(\mathrm{P}<0.05)$ heavier weight of rack compared to other treatment groups with similar values. Loin of rabbits fed T4 (50\% "Jigare" sorghum) diet had significantly $(\mathrm{P}<0.05)$ heavier weight than those fed control $(100 \%$ maize $)$ diet but did not differ from rabbits fed T2 (50\% "Chakalare" sorghum), T3 (100\% "Chakalare" sorghum) and T5 (100\% "Jigare" sorghum) diets. The loin weight expressed as percentage of slaughter weight followed the same trend as the slaughter weight. The shoulder, loin and thigh constitute over $90 \%$ of the carcass weight and thus rabbits with heavier shoulders, loins and thighs often have heavier carcasses (Igwebuike et al., 2007). The liver of rabbits fed T3 (100\% "Chakalare" sorghum), T4 (50\% "Jigare" sorghum) and T5 (100\% "Jigare" sorghum) diets were superior to T2 (50\% "Chakalare" sorghum) diet but was similar to rabbits fed control (100\% maize) diet. Rabbits fed control (100\% maize), T4 (50\% "Jigare" sorghum) and T5 (100\% "Jigare" sorghum) diets had significantly $(\mathrm{P}<0.05)$ heavier caecum weight than those fed T3 (100\% "Chakalare" sorghum) diet but similar to rabbits fed T2 (50\% "Chakalare" sorghum) diet. The stomach lengths of all the treatments with the exception of control (100\% maize) were similar. The carcass measurements of rabbits in this study compared favourably with the values reported by Mohammed et al. (2010) who slaughtered rabbits of similar weight and ages in the same environment. This suggested that complete replacement of maize with the two varieties of sorghum in the diet of growing rabbits had no adverse effect on carcass and organ developments.

\section{CONCLUSION}

Based on the haematological findings and carcass measurements of the rabbits, different varieties of sorghum ("Chakalare" and "Jigare") can replace $100 \%$ of the maize in the diets of growing rabbits. This is a good indication that different varieties of sorghum irrespective of 
its more or less tannin content can be fed to growing rabbits without compromising the health status and carcass yield of the rabbits.

\section{ACKNOWLEDGEMENTS}

Staff of Department of Animal Science, University of Maiduguri, Maiduguri, Borno State, Nigeria.

\section{REFERENCE}

Ahamefule, F. O., Obua, I. A., Ukweni, M. A., Oguike, M. A \& Amaka, R. A. 2008. Haematological and biochemical profile of weaner rabbits fed raw or processed pigeon pea seed meal-based diets. Afri. J. Agri. Res., 3(4): 315-319.

Ahamefule, F.O., Ibeawuchi, J.A \& Nwankwo, D. I. 2003. Utilization of sun - dried, fermented and ensiled cassava peel-based diets by weaner rabbits. Nig. Agri.. J., 3(5): 43-49.

Anon. 1980. Guide to the Care and Use of Experimental Animal Vol. I. Canadian Council on Animal Care, Ottawa, Ontario, Canada, pp. 85 -90.

Blasco, A., Ouhayoun, J \& Masoero. G. 1993. Harmonization of criteria and terminology in rabbit meat research. World Rabbit Science, 1(1): 3-10.

Duncan, D. B. 1955. Multiple range and multiple F. tests. Biometrics, 11: 1-42.

Encarta. 2007. Encarta Microsoft @ student 2007 (DVD). Redmond, W. A: Microsoft corporation.

FAO. 1991. Guideline for Slaughtering, Meat Cutting and Further Processing. FAO Animal Production and Health Paper No. 91. Food and Agriculture Organisation, Rome Italy. pp.176 - 181 .

Igwebuike, J. U., Anugwa, F. O. I \& Raji, A. O. 2007. Carcass characteristics of growing rabbits fed graded levels of Acacia albida pod. Sahel. J. Vet. Science, 6 (1): 45-50.

Jain, N. C. 1986. Veterinary Haematology $4^{\text {th }}$ ed. Lea - Febiger Publishers, Philadelphia. pp.

Mann, I. 1960. Meat Handling in under developed Countries. FAO Agricultural Development paper No. 70. Food and Agriculture Organisation, Rome Italy,

Mitruka, B, M \& Rawnsley, H. M. 1997. Clinical, biochemical and haematological reference values in normal experiment animals. Mason Publishing Company, New York. pp.35-50. 
Mohammed, G., Igwebuike, J. U \& Asheik, L. G. 2008. Utilization of cereal grains byproduct for feeding rabbits: A review. Nig. J. Exp. and Appl. Bio., 9(2): 139-144.

Mohammed, G., Igwebuike, J. U., Medugu, C. I., Kwari, I. D and Ahamed, U. 2010. Effect of feeding graded levels of Tigernut (Cyperus esculentus) residue on haematological parameters and carcass characteristic of growing rabbits. Proc. $15^{\text {th }}$ Conf. Anim. Sci. Assoc. of Nig. (ASAN) 13-15 ${ }^{\text {th }}$ Sept, 2010. University of Uyo, Nigeria. pp. 227-229.

Ojebiyi, O. O., Farinu, G., Babatunde, G. M \& Moronfolu, O. O. 2006. Effect of varying levels of sun-dried cassava peel - blood meal mixture (3:2) on growth performance and organ characteristics of weaner rabbit. J. Anim. Vet. Advances, 5(11): 886-890.

Owen, O. J., Alawa, J. P., Wekhe, S. N., Isirimah, N. O., Ngodigha, E. M. \& Amakiri, A. O. 2009. Incorporation of poultry litter in rabbit feed: A solid waste management strategy. Egypian. J. Anim. Production, 46 (1): 63-68.

Schalm, O.W., Jain, N.C \& Carrol, E. 1975. Veterinary haematology. 3rd Edition, Lea and Febiger, Philadelphia, USA. pp 160-210.

Steel, R. G. D \& Torrie, J. A. 1980. Principles and Procedures of Statistics. A Biometrical Approach, $2^{\text {nd }}$ Edition, Mc Graw-Hill Book Co. Inc. NewYork, 633 p.

Ugherughe, P. O \& Ekedolum, P. A. 1986. Pasture and rangeland potentials. Annals of Borno, 3: 179-192. 